\title{
The Impact of College on the Development of Tolerance
}

\author{
Simone Himbeault Taylor
}

\begin{abstract}
The author considers the distinct constructs that define moral development and the effect that college has both on moral development and the subsequent development of such attitudes as tolerance. She presents the implications for institutional practice, especially with regard to the influence of college environment and the role of higher education in developing students along all parameters of moral development and attitude reformation.
\end{abstract}

The role of higher education, as described by Boyer (1987), is to prepare students to live lives of dignity and purpose, promote the public good, and educate a citizenry that can function in an increasingly diverse world. Yet, there is mounting evidence of a growing resistance to change among this country's citizens along with a growing fear of people different from themselves. Examples of a lack of tolerance toward differences in race, gender, and sexual orientation abound. Given that Johnston and Parker (1987) project that by the year 2000, women, people of color, and non-U.S. citizens will make up a substantially growing portion of the U.S. labor market, an appreciation for diversity would seem to be among the most critically useful values; such attitudes, however, seem to be waning dramatically.

Simone Himbeault Taylor is Director of the Office of Planning and Placement, Division of Student Affairs; at the LIniversity of Michigan-Ann Arbor. Dr. Taylor received the NASPA Melvene Hardee Dissertation of the Year Award for the research upon which this article is based. 
Astin (1993) observed that "a frequently stated purpose of liberal education is to promote greater tolerance and open-mindedness among students" (p. 146), yet college campuses are, unfortunately, not immune to a lack of tolerance for human differences. One need only superficially scan the Chronicle of Higher Education over the past decade-a period during which campuses have become more broadly reflective of the diversity of the population at large- to observe the inability of college students to coexist peacefully. Evidence of hate speech and the harassment of women, racial and ethnic groups, and gay and lesbian students abounds (Knefelkamp, 1992).

As higher education is viewed increasingly as a tool for individual economic advancement, its role in building character has been given less prominence (Pascarella \& Terenzini, 1991). Published reports on the importance of establishing a sense of values among students have warned institutions that to ignore this important role is to create an educated mass that may have learned to "make a living" but not "how to live" (Sanford, in Wheatley, 1982, p. xv). Today, with an increasingly heterogeneous population of college students, educators are re-examining the academy's role in influencing the shaping of the values of its students, and there is a renewed interest in making values' development an explicit, critical component of higher education. Today, the role of higher education is not to inculcate particular values but to teach students "how to value" (Morrill quoted in DeCoster \& Brown, 1991, pp. 596-599).

The need for tolerance in society sets the stage for higher education's role in the development of citizens who possess a concern for others. Current researchers and policymakers advocate that this is an important, indeed paramount, role for higher education (Dalton, 1992; Kitwood, 1990). It is this nexus-the point where the development of students' tolerance comes together with the effect of an institution's influence in that developmentthat is the focus of this study (Taylor, 1994). Specifically, the research question addressed in this study is: How do college experiences contribute to developing greater tolerance for diversity in college students?

\section{Literature}

Moral and cognitive development theories, interactionist theory, and principles pertaining to the impact of college on students form the conceptual basis for the study. Moral and cognitive development theories address many developmental issues; critical to this study are those works that challenge traditional notions of stage development. These include the challenges to Kohlberg's model of moral development $(1975,1981)$ and 
those theories that consider alternate developmental stages focusing particularly on how females and males may differ in their developmental progressions. Some current moral and cognitive development theories that take gender into consideration may, however, be creating false dichotomies that emphasize gender distinctions while minimizing social considerations. Gilligan (1982), for example, promotes the gender-related dichotomous voices of justice and care; and, Belenky, Clinchy, Goldberger and Tarule's (1986) cognitive theory delineates discrete female and male ways of learning, that is, for females, connected learning, and for males, banking. Baxter Magolda (1992) comes closest to bridging this cognitive and social gap by defining common developmental stages for both genders while suggesting that females and males tend to take different paths toward reaching these stages. Generally, however, cognitive and interpersonal aspects of development have been seen largely as separate concerns with differences often accentuated by gender; this matter is addressed in the research model used in this study.

Interactionist theory contributes to an interrelational view of understanding the development of tolerance. From this perspective, development occurs as a result of an ongoing exchange between the self and multiple collectives (Apfelbaum, 1979; Globetti, Globetti, Brown, \&Smith, 1993; Pettigrew, 1985; Tajfel \& Turner 1986; Zanden, 1987). The notion of possible selves, that is, imagining and testing the personal options associated with defining one's self (Markus and Nurius 1986), is particularly useful as a means for understanding any gender differences that may exist. This theory also provides a rationale for focusing on White students in studying the development of tolerance. An interrelational view of tolerance suggests that majority as well as minority populations must recognize and respond to the complexities and interplay of race, gender, and sexual orientation and to the social status and power dimensions associated with them. For some group associations, these social structures involve subordinating strictures imposed by the majority that impede the equal distribution of resources, including the distribution of power (Davis, 1991; West \& Zimmerman, 1987).

Literature that explores the impact of college reinforces sociological theory by examining socializing influences specific to the college experience (Astin, 1993; Boyer, 1990; Deppe, 1989; Kuh, Schuh, Whitt et al., 1991; Pace, 1990; Tierney, 1992). Examination of college micro-environments has been limited, especially in linking the impact of college to attitudinal development (Pascarella \& Terenzini, 1991). What truly affects attitude change? Is it simply the socializing influence of college or might it be the changes in moral development that would occur only when the student is actively engaged in the college experience? There is renewed interest within higher education in engendering values in students especially with 
regard to diversity and multiculturalism, which West (1996) refers to as multicontextualism. What remains to be better understood is the extent to which tolerance may be developed, how such development occurs, and what evidence exists to support the notion that college experiences influence tolerance. By considering more fully the confluence of moral development and the social impact of college, the gap between attitude development and tolerance that exists in current theory may begin to be bridged.

\section{Model}

Tolerance is broadly defined in terms of an openness to human differences that leads to acceptance and respect; this is associated with Chickering and Reisser's (1993) fifth vector; Dewey's (1959) associated living; and Kohlberg's (1975) and Boyer's (1990) principles of a just community. Diversity is defined as involving human differences, whether of race, gender, sexual orientation, or any other biologically derived or socially constructed characteristic; individuals may reflect multiple characteristics.

The research design for this study offers a plan for understanding the development of tolerance in White students and attempts to bridge the gap between moral development and social factors missing from other moral development and college impact models (Figure 1). White students were selected because they represent the majority population at predominantly White institutions, where their attitudes play a substantial role in defining the culture for all students. The model proposes that students bring to college a composite self, composed of levels of moral development, aptitudes, and sets of experiences (e.g., family education, social network, religiosity) that contribute to their initial level of tolerance. These background characteristics create a context for understanding the students' initial level of tolerance when entering college and how this initial tolerance is changed or moderated by college micro-environments, such as institutional values toward multiculturalism, perceptions of campus harmony, and diversity-related academic, cocurricular, and peer involvement. The model further suggests that college experiences influence moral development and, ultimately, attitude formation-in this case, the development of tolerance. A working premise of the study is that openness to the college experience and to meaningful college involvement results in enhanced moral development, which, in turn, influences the level of tolerance. 
Figure 1

Research Design for Causal Path Model Studying the Development of Tolerance in College Students
Pre-College Student
Entering Tolerance
College Involvement
Moral Development after Second Year of College
Tolerance after Second Year of College

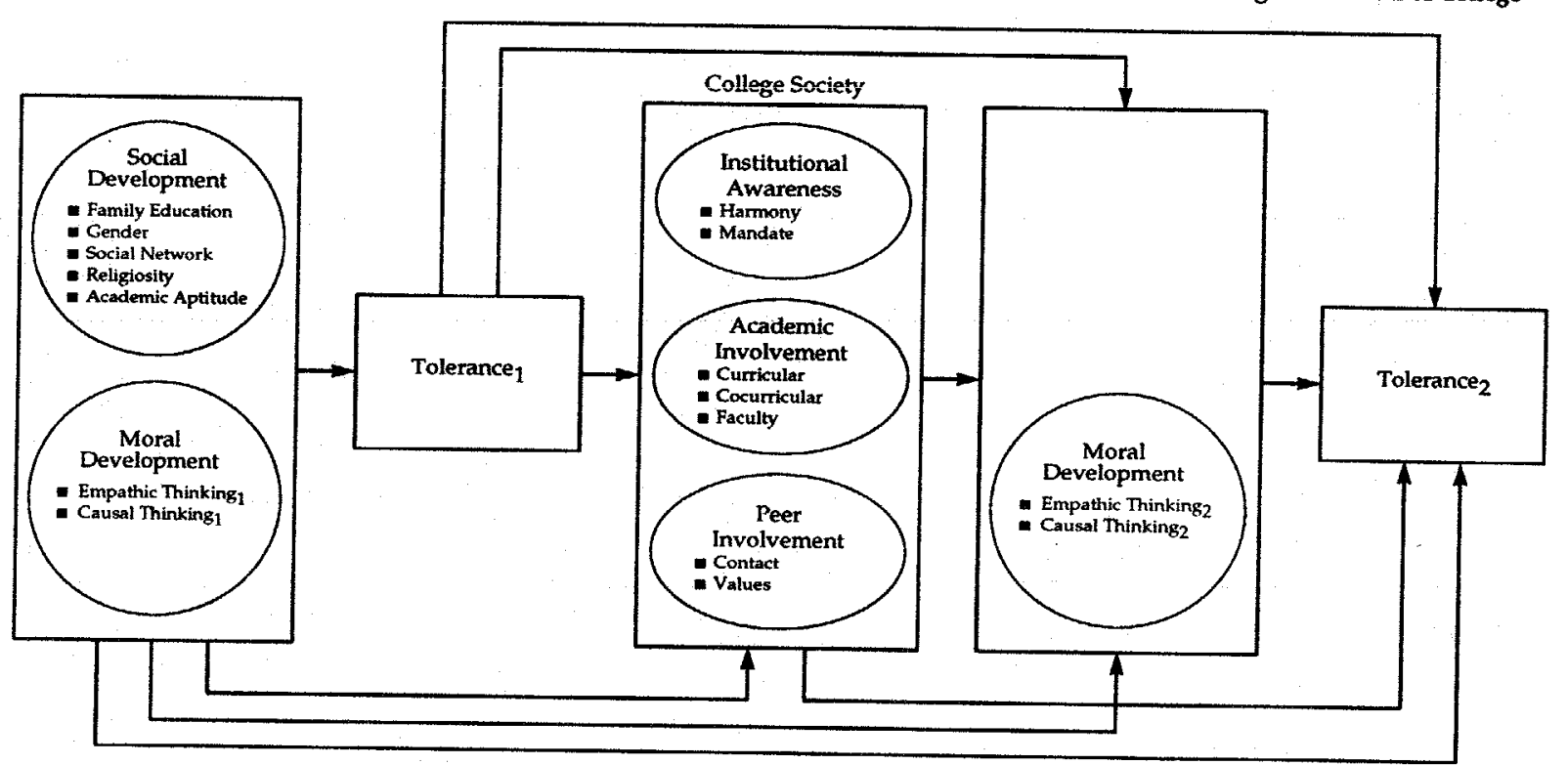


As indicated in the review of the literature, some current moral and cognitive development theories that take gender into consideration may be creating artificial distinctions by emphasizing unique moral orientations, orientations that tend to separate the cognitive from the interpersonal. In this research model, moral development is defined through two distinct decision-making processes that are both cognitive and interpersonal in nature, empathic thinking and causal thinking. Empathic thinking encompasses the consideration of multiple points of view in decisionmaking processes generally associated with progressing from simplistic to more complex thinking (Davis, 1983). Causal thinking, sometimes referred to as attributional complexity, is a thought process associated with analyzing those reasons or causes for people's behaviors which are then taken into consideration in decision-making (Fletcher, 1986). Empathic and causal thinking are presented as complementary constructs, accessible to both genders, which ultimately contribute to advancing moral development and, in turn, tolerance The model does not rule out the existence of additional cognitive and interpersonal constructs.

\section{Methodology}

\section{Analytical Design}

With a theoretical model in place and data measuring change over time, a predictive model for tolerance was explored. A recursive path analysis model using Ordinary Least Squares [OLS] regression was the statistical technique chosen to investigate causal relationships. Principle component factor analysis with Varimax rotation was employed for data reduction from which indices were then created. An iterative process, including examining descriptive statistics and performing t-test and bivariate analyses, ensured a viable transition from the research design to a sound statistical model

Three hierarchical multiple regressions were performed to examine the relative contribution of each measure in the model to the final measure of tolerance. Hypotheses regarding gender differences were established a priori, and the model was tested for the total sample and by gender. Separate path analyses were conducted for the total sample and by gender to further investigate the nature of direct and indirect relationships between independent measures and with the outcome. Direct, indirect, and total effects were calculated to establish the overall impact of the model. T-delta tests of the gender analyses were calculated to compare the statistical models. Tests for interactions were performed. Residual 
analyses were conducted in order to test for adherence to the assumptions of normality and homoscedasticity. Given a .05 level of significance and 18 variables, if significant differences existed within the model, a sample size of 575 would provide sufficient power to establish differences.

\section{Instrument and Sample}

In order to observe change in students resulting from institutional intervention, it was important to study an institution with a diverse student body and an articulated position regarding multiculturalism Such conditions were present at a large Midwestern research university, with 50,000 students, approximately 36,000 of whom are undergraduates. The institutional study from which this secondary data analysis is derived followed the impact on students of the university in general and, in particular, the institutional diversity mandate-a values statement for multiculturalism approved in 1987. ${ }^{1}$ Students were tracked from their entrance in Fall 1990 to their graduation. Given that the study of tolerance was related to the institutional study, it was deemed appropriate to test the theoretical model on this data.

Baseline data were gathered using surveys that were distributed to all first-year students living in residence halls during the first week they were at the college; data collected during the students' second year were used to test the model. The response rate for White students was $57 \%$ for the initial survey, and $53 \%$ for the second year. Preliminary analyses indicated no striking biases between survey respondents and the institutional profile of entering students. As indicated earlier, because the study specifically examined the influences on tolerance of White students, data were drawn from the sample of White U.S. citizens for whom complete data were available from both survey points ( $N=575 ; 52 \%$ female). The criterion used for acceptance of subjects into the sample pool was that they had answered at least 9 of the 11 items in the index for the dependent variable, tolerance.

\section{Operationalization of Variables}

Drawing from the institutional study, variables were selected to represent each of the constructs identified in the research design. In many cases, indices were created utilizing principle component factor analysis,

\footnotetext{
${ }^{1}$ Acknowledgement is given to the Office of the Vice Provost for Academic and Multicultural Affairs University of Michigan-Ann Arbor for access to the data used in The Michigan Study (1990-1994): A Study of Diversity in Higher Education. The views expressed in this document do not necessarily reflect the views of the Office of the Vice Provost.
} 
allowing the incorporation of multiple survey items into a single, cohesive item best reflecting the construct. While space prevents detailing each variable, the operationalization of the dependent variable, tolerance, bears consideration.

For the purposes of this study, tolerance is defined broadly as an openness to human differences, which leads to the acceptance, respect for, and genuine celebration of diversity. Conceptually, it is not tolerance toward any specific singular group (e.g., race, gender) that is of interest in this study but rather the more global openness described in the traditional student development literature. Translated to a measure, tolerance captures attitudes toward a subset of social groups, specifically, race, gender, and sexual orientation, in order to create a general measure of tolerance. In the end, eleven survey items conceptually captured this definition in a factor with an overall reliability (alpha) of .71 at point of entry and .79 in the second year. Attitudes toward race were captured through such items as those which asked: whether society has done enough to promote the welfare of people of color; whether the system prevents people of color from "getting their fair share of the good things in life;" whether racial background impedes success in society; and about attitudes towards openness concerning interracial dating. Items relating to attitudes toward women included those about the role of women in the work world and as homemakers, and the degree to which females are taken as seriously as males academically and given attention in the classroom. Attitudes toward sexual orientation were reflected in items that indicated whether students perceived same-gender romantic and sexual relationships as acceptable and whether they would maintain friendships with and provide support to lesbians, gays, or bisexuals.

\section{Results}

T-delta test ${ }^{2}$ comparing the gender models in this study indicate that the model is legitimate for both females and males. Analysis of the research model indicates that it is informative, accounting for $61 \%$ of the explained variance for females and $48 \%$ for males. Key findings support the major hypotheses. Important differences by gender are present: females demonstrate higher levels of tolerance at entering college than do males and experience almost three times the gains in tolerance during the first

${ }^{2}$ T-delta analyses provide for a comparison across two path models. In this case, it allows comparison of the model variables between genders. Estimates are derived using the following formula, where $b=$ unstandardized regression coefficient $\left(b_{1}=\right.$ female; $b_{2}=$ male $)$ and $S E=$ standard error term:

$$
t-\Delta \text { calculation }=\sqrt{\left(S E b_{1}\right)^{2}+\left(S E b_{2}\right)^{2}}
$$


two years of college. On a 1 to 5 scale in the direction of increasing tolerance, females moved from 2.67 to 2.81 ( $p \leq .001$ ) and males from 2.42 to 2.47 ( $\mathrm{p} \leq .05)$. While the actual size of the effect is modest, it does reflect a significant trend after only two years of college. Path analyses reveal that gains result from the strong and enduring influences of pre-college socialization, the effects of selected college experiences, and the impact of enhanced moral development that differs by gender.

For females, a theme emerges regarding the important and enduring aspects of pre-college socialization. For example, a mother's level of education, a pre-college socialization measure, is a strong contributor (direct/ total effect $\beta=.12(p \leq .01) / .17)$. In addition, selected college experiences have the ability to influence moral development, especially in terms of a causal view of the world. This, in turn, contributes to heightened tolerance. For example, except for tolerance at entrance, which is, of course, the strongest predictor of final tolerance, the repeat measure of causal thinking (direct/total effect $B=.17(p \leq .001) / .17)$ contributes the greatest effect by far, followed by perceptions of the institution's commitment to multiculturalism (direct/total effect $B=.15(p \leq .001) / .16)$. It is the change in causal thinking that contributes measurably to enhanced tolerance rather than empathic thinking, which contributes only at the time of college entrance.

For males, the dominating theme is the direct impact of the college experience on tolerance. Precollege socialization influences, while important for establishing initial levels of tolerance in males, diminish in importance. Furthermore, while moral development parameters are important to male development, their effect is largely captured within entering tolerance. College environment constructs have a direct effect on enhancing tolerance in males but have little effect on moral development. For example, following levels of tolerance at entrance, the greatest influence on tolerance by far is the perception of institutional commitment to multiculturalism (direct/total effect $\beta=.21(p \leq .001) / .21)$ followed by cocurricular involvement in multicultural issues (direct / total effect $B=.14$ $(p \leq .01) / .13)$. Male tolerance is affected more directly by the college experience, but the fact that males do not substantially engage in a complex level of causal thinking during the first two years of college suggests that they are not, on average, benefiting as fully as females from the enhanced moral development that leads to heightened levels of tolerance This is consistent with the fact that males were found to change very little.

Thus, the overall findings indicate that the college experience influences tolerance for both White females and males but that there exists an enhancing quality associated with causal thinking for females which contributes to their more substantial gains. Of special note is the fact that of 
the college involvement constructs, students' awareness of the impact of an institution's commitment to diversity is one of the most consistently powerful predictors of tolerance for both genders. While other predictors emerge as influential, no others hold its level of influence. This is an important message to institutions of higher education seeking to influence the development of students. ${ }^{3}$

\section{Discussion}

\section{Research Implications}

These findings hold significance for both the theory and practice of student affairs and higher education. This study lends credence to the notion that enhanced tolerance is the result of two distinct cognitive and interpersonal moral orientations. The findings support the cognitive emphasis in Baxter Magolda's (1992) work; instead of isolating interpersonal parameters, however, the findings suggest additionally that two unique dimensions of complex thinking involve cognitive and interpersonal factors concurrently which represent enhanced moral development. This is a particularly critical finding of this study.

To develop tolerance requires a causal thinking perspective; this is a perspective nurtured and engaged in more fully in females than in males, resulting in their greater tolerance. It is interesting to speculate why this may be the case, especially as the notion of causal thinking is a somewhat underrepresented perspective in the moral development literature. Much of the existing student development literature reinforces the underlying assumption that moral development occurs within a societal context, and that cognition and values development are consistently and inextricably linked to the social realm. Yet, when examined closely, the social context for moral development is embedded, theoretically, in a given environment, leading to an interesting observation.

\footnotetext{
${ }^{3}$ One might argue that awareness of diversity efforts may make it more likely that students would provide socially acceptable responses. We can, with some confidence, discard this rival hypothesis. Care was taken to pose questions in language that would provide a comfortable context to respond in either agreement or disagreement. For example, one question making up this four question factor asked students to indicate the degree to which they agreed or disagreed with the statement, "The University commitment to diversity fosters more division among racial/ethnic groups than inter-group understanding." Success in providing a venue for the wide range of responses is evidenced in the fact that over $60 \%$ of all White respondents indicated agreement or strong agreement with this statement, which reflects a more negative than positive view of institutional diversity efforts.
} 
As with tolerance, an initial decision-making perspective that incorporates more complex causal thinking may yield even greater complexity along these dimensions. The study's finding that females enter college demonstrating greater levels of causal thinking and entering tolerance than males and, after at least two years into the college experience, demonstrate significant growth in these areas is perhaps not serendipitous. May it be that the traditionally subjugated role of women in society leads them to develop-well before attending college-highly refined causal thinking, not despite repressing social status and power issues but as a result of them? Gilligan (1982) and Baxter Magolda (1992) both infer this could be the case. Subordination, then, serves as a catalyst for thinking about systemic causation, in addition to individual causation, which paves the cognitive path for tolerance. Moral development theory underscores the importance of role taking. May it be that this developed appreciation of complex causes for people's behaviors results in a freeing capacity which permits those with initially higher levels of causal thinking to experiment and role play - before and during college-in such a way as to gain fluency in both causal and empathic thinking? Liddell, Halpin, and Halpin (1993) support this interpretation, indicating that women demonstrate presence in both justice and care orientations whereas males concentrate within justice. Markus and Nurius (1986) promulgate the concept of possible selves. Findings from this study would further suggest that while imagining, reimaging, and testing out of possible selves may be more initially accessible to females as a result of their traditionally subjugated status in society (which may foster a greater initial connection with themselves to society through causal thinking), it is not strictly within the domain of females.

\section{Implications for Educational Practice}

The findings of this study have implications for institutional practices especially with regard to the influence of college micro-environments and the role of higher education in developing students along all parameters of moral development and attitude reformation These include implications at the policy and programmatic levels inside and outside the classroom (Smith and Taylor, 1995). A few of these implications are highlighted as follows:

- Institutional values matter. This study provides evidence that the institution's own expressed and actualized value systemmodelled at the highest levels-bears a direct association with the values that develop in students. Institutions need to clearly delineate their values; transmit them both in writing and through the words and deeds of the faculty, the staff, and the educational services they provide; and live them in a manner that is perceived as being important and genuine to students. We are reminded of Morrill's assertion that the role of higher 
education is not to inculcate particular values but to teach students how to value (cited in DeCoster \& Brown, 1991).

- Students are complex cognitive and interpersonal individuals. Institutions wishing to have the greatest impact on students need to attend to the total development of students and not only part of them. Students do not live unidimensional lives but complex ones that incorporate multiple roles, and these roles, in turn, influence their college experience The degree to which students are actively engaged in the college environment affects the impact colleges are likely to have on them and explains why the college experience appears to have a greater effect on some students than on others. Thus, administrators, faculty, and staff seeking to engender the highest level of development in students will attend to both their cognitive and interpersonal dimensions.

- $\quad$ Engendering tolerance in college students is everyone's responsibility, shared by all members of the educational community. These findings lend credence to attending to the total educational experience as evidenced through the strong impact of tolerance- and diversity-related cocurricular activities. This serves as support for the value of student affairs, a division that has been traditionally charged with responsibility for the out-of-classroom educational experiences of students. It also supports the development of an educational community that blurs the lines between academic and non-academic environments and places an emphasis on student learning, whether it occurs within or outside the traditional classroom.

- Programmatic interventions should take into account a potential for differential impact on students. The nature of students' psychological and social identities has implications for how and at what point college influences student development. This study points out the importance of institutions knowing their students. The impact of the college experience may, for example, vary by gender or ethnicity, necessitating multiple approaches to issues. In this study, it was found that while females were similarly influenced by classroom and cocurricular diversity experiences, males were more affected by out-of-classroom experiences. In higher education, one size does not fit all.

- This study confirms the belief that institutions should appreciate the fact that students enter college with existing attitudes. In addressing issues associated with enhancing tolerance, higher education is engaging in the reformation, not the formation, of values. This places higher education in the role of a social change agent. Education is not a neutral process. 


\section{Conclusion}

We are brought back then to consider one of the key purposes of higher education: to prepare students for citizenship in society. If our role as educated citizens is to guide society toward a good society, to promote humanitarian ends, and build future leaders, as Boyer (1987) suggests, today's college students need a place to practice ethical decision making. The literature suggests that institutions of higher education should and can be a viable place for students to practice ethical decision making. By better understanding the distinct constructs that define moral development and the effect the college experience has on both moral development and the subsequent development of such attitudes as tolerance, higher education may again become "a dwelling place for the human spirit" (Laney, quoted in May, 1990, p. 59) and prepare students to be value driven contributors to society. Higher education institutions are in a strong position to develop citizens of the world with the skills to provide informed and humane guidance to society. Kitwood (1990) tells us that "the good society is one which, above all else, allows relationship [sic] to flourish. Whatever may be its political form, this is its psychological desideratum" (p. 9). Higher education can be a form of the good society where students practice and develop the complex cognitive, interpersonal characteristics associated with sophisticated moral decisionmaking. In a good society, moral decision-making matters; it is its desideratum.

\section{References}

Apfelbaum, E. (1979). Relations of domination and movements for liberation: An analysis of power between groups. In W. G. Austin \& S. Worchel (Eds.), The social development of intergroup relations (pp. 188-204). Monterey, CA: Brooks/Cole.

Astin, A. W. (1993). What matters in college? Four critical years revisited. San-Francisco: Jossey-Bass.

Baxter Magolda, M. (1992). Knowing and reasoning in college: Genderrelated patterns in students' intellectual development. San Francisco: JosseyBass

Belenky, M. F., Clinchy, B. M., Goldberger, N., \& Tarule, J. M. (1986). Women's ways of knowing. NY: Basic Books.

Boyer, E. L. (1987). College: The undergraduate experience in America. NY: Harper \& Row.

Boyer, E. L. (1990). Campus life: In search of community. Princeton: The Carnegie Foundation for the Advancement of Teaching.

Chickering, A., \& Reisser, L. (1993). Education and identity. (2d ed). San Francisco: Jossey-Bass. 
Dlaton, J. (March, 1992). A model for linking academic and student affairs in promoting values outcomes. Paper presented at the National Association of Student Personnel Administrators National Conference, Cincinnati, $\mathrm{OH}$.

Davis, F. J. (1991). Who is Black? One nation's definition. University Park: The Pennsylvania State University Press.

Davis, M. H. (1983). Measuring individual differences in empathy: Evidence for a multidimensional approach. Journal of Personality and Social Psychology, 44, 113-126.

DeCoster, D. A.; \& Brown, S. S. (1991). Staff development: Personal and professional education. In T. K. Miller \& R. B. Winston, and associates (Eds.). Administration and leadership in student affairs: Actualizing student development in higher education. Muncie, In: Accelerated Development.

Deppe, M. (1989, November). The impact of racial diversity and involvement on college students' social concern values. Paper presented at the Annual Meeting of the Association of the Study of Higher Education, Atlanta, GA.

Dewey, J. (1959). Dewey on education. NY: Teachers College Press.

Fletcher, G. J. (1986). Attributional complexity: An individual differences measure. Journal of Personality and Social Psychology, 51, 875884.

Gilligan, C. (1982). In a different voice: Psychological theory and women's development. Cambridge, MA: Harvard University Press.

Globetti, E. C., Globetti, G., Brown, C. L., \& Smith, R. E. (1993). Social interaction and multiculturalism. NASPA Journal, 30, 209-218.

Johnston, W., \& Parker, A. (1987). Workforce 2000: Work and workers for the 21st century. Indianapolis, IN: Hudson Institute.

Kitwood, T. (1990). Concern for others: A new psychology of conscience and morality. London: Routledge.

Knefelkamp, L. L. (1992). The multicultural curriculum and communities of peace. Liberal Education, 78, 27-35.

Kolhberg, L. (1975). A cognitive-developmental approach to moral education. Phi Delta Kappan, 56, 670-677.

Kohlberg, L. (1981). The philosophy of moral development: Moral stages and the idea of justice. San Francisco: Harper \& Row.

Kuh, G. D., Schuh, J. H., Whitt E. J., \& Associates. (1991). Involving colleges: Successful approaches to fostering student learning and development outside the classroom. San Francisco: Jossey-Bass.

Laney, J. T. (1990). Through thick and thin: Two ways of talking about the academy and moral responsibility. In W. May (Ed.), Ethics and higher education (pp. 49-66). NY: ACE and Macmillan.

Liddell, D. L., Halpin, G., \& Halpin, W. G. (1993). Men, women, and moral orientation: Accounting for our differences. NASPA Journal, 30, 138144.

Markus, H., \& Nurius, P. (1986). Possible selves. American $P_{\text {sychologist, }}$ 41, 954-969.

May, W. (1990). Ethics and Higher Education. NY: ACE and Macmillan.

Pace, C. R. (1990). The Undergraduates. Los Angeles: UCLA, Center for the Study of Evaluation. 
Pascarella, E. T., \& Terenzini, P. T. (1991). How college affects students. San Francisco: Jossey-Bass.

Pettigrew, T. F. (1985). New black-white patterns: How best to conceptualize them. Annual Review of Sociology, 11, 329-346.

Sanford, N. (1982). Introduction. In J. Whiteley. Character development in college students. Schenectady, NY.: Character Research Press.

Smith, K. M., \& Taylor, S. H. (1995, June). Using assessment and quality initiatives to enhance diversity and improve campus climate. Paper presented at the American Association for Higher Education Annual Assessment and Quality, Boston, MA.

Tajfel, H., \& Turner, J. C. (1986). The social identity theory of intergroup behavior. In S. Worchel \& W. G. Austin (Eds.). Psychology of intergroup relations (pp. 7-24). Chicago: Nelson-Hall.

Taylor S. H. (1994). Enhancing tolerance: The confluence of moral development with the college experience. (Doctoral dissertation, University of Michigan, 1994). Dissertation Abstracts International, 56, A114.

Tierney, W. G. (1992). An anthropological analysis of student participation in college. Journal of Higher Education, 63, 603-618.

West, C. (1996, March). Paper presented at the National Association of Student Personnel Administrators National Conference, Atlanta, GA.

West C., \& Zimmerman, D. H. (1987). Doing gender. Gender and Society, 1, 125-151.

Whiteley, J. (1982). Character development in college students. Schenectady, NY: Character Research Press.

Zanden, J. W. V. (1987). Social Psychology. NY: Random House. 